\title{
Persistence of African languages and religions in Latin America since slavery
}

\author{
Ndapewa Fenny Nakanyete ${ }^{1}$ \\ University of Namibia
}

\begin{abstract}
This paper examines the presence of African languages and spiritual practices of Candomblé, Santería and Vodou religions in Brazil, Cuba and Haiti respectively. The three religions are known to have been originated by African slaves that were mostly captured in- and transferred from West and Central Africa to Latin America. Currently, the three religions are not only followed by African descendants, but also by people of various ethnic backgrounds worldwide. Thus, people flock to the three countries regularly to be initiated into this African-based religions and cultures. On the other hand, similar spiritual practices on the African continent seem to be generally stigmatized if not demonized. Findings presented in this paper are as a result of direct observations and open interviews over a four months of fieldwork, as well as desktop reviews of existing literature. The findings demonstrate etymologies of terms and expressions that are of various African languages origin and are used in the three religions. The paper calls for integral comparative studies of parts in Africa with parts of Latin America to auxiliary identify linguistic and spirituality similarities, and significance roles of African slaves in maintaining African traditions.
\end{abstract}

\section{Introduction}

Since childhood I have been very curious about African spirituality. I remember how I sneaked out of my Christian home as a seven-year-old girl late in the evening to go witness efundula lomeengoma, an initiation ceremonial process directly translated as a wedding through drums, where ovafuko (brides) collectively celebrate their initiation ceremony before finding husbands. It is during this particular ceremony that our ovakwamhungu (ancestral spirits) are praised upon, through okutyatyala (ritual dances) and the beatings of eengoma (drums). All these religious practices are conducted under the supervision of Namunganga or omupitifi, a ritual leader/diviner who becomes spiritually possessed (Kautondokwa, 2014). It was during this event that I became closest to the spirituality that my foremothers and forefathers assumingly proudly embraced; religious practices that one can no longer really openly talk about without being stigmatized as a sinner by believers of the main religion in Namibia, Christianity.

Unfortunately, the traditional spirituality of the Ovawambo people who once believed in Kalunga kaNangobe as the supreme God and worshipped the Ovakwamhungu, the spirits of the ancestors - has almost disappeared. Since the introduction of Evangelism from as early as 1870 in kingdoms

\footnotetext{
${ }^{1}$ Ndapewa Fenny Nakanyete is lecturer at the University of Namibia. She has been offering various Geography courses particularly in Human Geography since 2014. Her research experiences and interests lie under broad themes of culture and indigenous knowledge, gender, land use, urban and rural environments, and development. She holds a Bachelor of Arts Degree in Geography and Sociology from the University of Namibia, a Master Degree in Geographic Information Technologies from the Autonomous University of Barcelona (Spain), and is currently on study leave pursuing an interdisciplinary Master of Arts degree in Culture and Environment in Africa at the University of Cologne (Germany). Email: nnakanyete@unam.na or ndapewafenny@gmail.com
} 
that make up Namibia today, about $80 \%$ to $90 \%$ citizens are estimated to have converted to Christianity with only $10 \%$ to $20 \%$ of citizen estimated to continue following their traditional beliefs (Hiltunen, 1993, p.16; Bialostocka, 2015, p. 1). The decreasing number of African spiritual followers in the country may signify the disappearance of traditions including idioms and cultures. Exploring African-based religious beliefs outside the continent could be one of the possible ways to preserve relevant but endangered intangible heritage, and to re-introduce significant practices that have been lost back to the continent. It is against this background that I endeavored to experience, learn and document main religious beliefs of Africans descendants outside the continent, the beliefs that were conveyed by African slaves who would rescript and /or maintain their religions of Candomblé, Santería and Vodou after their relocation to the Americas over 300 years ago.

From $16^{\text {th }}$ to 18 th centuries, a vast amount of Africans, predominantly from central and western Africa were sold into slavery and forcefully taken across the Atlantic to the Americas to be exploited as cheap labourers by their masters. Mason (2015) estimates more than 11 million African slaves mainly from Yoruba and Bakongo tribes who were traded into Brazil, Cuba, Haiti and United States alone, while Karade (1994) gives a total estimate of 75 million captives to have been taken to the rest of New World countries for four or five centuries to predominantly work on sugar, tobacco, coffee, rice, and cotton plantations (p. 4). Throughout this captivity, slaves were prohibited by the Catholic Church from practicing their customary religions that they brought with from their homelands. However, they secretly maintained their traditional spirituality and practiced their beliefs notwithstanding the oppressive Catholic communities.

Religious beliefs such as Candomblé, Umbanda, Xango, and Batique in Brazil; Vodou in Haiti; and Santería or Ocha and Palo Mayombe in Cuba are among the strongly rooted African historic cultural and spiritual practices (Murrell, 2010). In this paper I attempt to highlight the religions of Candomblé, Santería and Vodou, in terms of their origins, practices and associations with one another. The ideas expressed in the paper are the results of direct observations I made as I travelled in Brazil, Cuba and Haiti, open interviews with followers of these religions and ordinary local people for individual knowledge and experiences, as well as literature review.

Fieldwork took place between 2016 and 2018. In sum, I had four months visits to learn and document the enriching knowledge that African-origin spiritual believers of the above mentioned religions have carried along during slavery in the Americas. Although the utmost information presented in this paper was mainly obtained from secondary sources and my personal observations, six interviews were conducted to supplement the findings. For these interviews, informants were selected either as followers of the religions or local experts with firsthand knowledge about the religions. Informants were selected using a convenience sampling method, based on their availability.

\section{Languages through the religions of African slaves in Latin America}

Despite their capture and forced relocation to the Americas, African slaves maintained their expressions in their own languages. Phrases in languages such as Yoruba and Kikongo are used up to this date in religions practices of African origins found in Latin America. It is estimated by Mason (2015) that ninety-nine percent of these African slaves came from an approximated area of over $1800 \mathrm{~km}$ wide by $10360 \mathrm{~km}$ long, stretching from today's Senegal and Mali in the north to Zaire and Angola in the south. Even with such diversity, there was coherence in their language and tradition bases including concepts about God. Heine and Nurse (2000) explain that in countries such as Haiti, Brazil, Suriname and Jamaica, African slaves were initially the creators 
of creole languages that were developed through mixing their (slaves) closely related languages with European languages for new ones, while simultaneously preserving them through the rituals they collectively practiced. It is these acquaintances that played key roles in soothing the throbbing impact of slavery, leading to cultural mixtures that were already ongoing within the African continent before slave trade accelerated. As a result, the creolization of African languages created combined cultures and religions from the assemblage of such diversity.

There are linguistic and cultural evidences found in practices of the three religions in Latin America. Languages and cultures such as Yoruba, which is often made reference to in these religions, is still diversely spoken and practiced by close to 30 million people in West Africa, predominantly Nigeria (Omoregbe, Azeta, Adewumi \& Omotoso, 2014). This leaves no doubt to argue that the religions of Candomblé, Santería and Vodou in Latin America were as a result of Africa slaves transporting their languages and practices with them out of the African continent. Finding common expressions and spiritual or cultural practices in these religions as in existing traditional rituals and spoken languages in Africa is one practical example. Phrases like "Așé" (also spelled in various ways, such as: Ase, Ashe, Axé, etc), which is used to refer to the mystical power of making things happen (Karade, 1994) - is one of the shared philosophical concepts Candomblé and Santería believers have in common with Yoruba people in West Africa. The origins of this phrase is traced to Yoruba language. Other examples of names or phrases derived from African languages in the religions are explained in the units below.

While attempts of banning the three beliefs were made in Brazil, Cuba and Haiti, where slaves were forced into Catholicism, a number of slaves maintained their beliefs alongside Christianity. Today, the majority of Caribbean people consider themselves as Christians, Muslims, Hindus, or Buddhists at the same time recognize and practices Vodou and Santería; creole elite people were taught to despise the African heritage that numerous peasants kept alive (Murrell, 2010).

Today, the above mentioned religions are not only practiced by the majority of the afrodescendants but also by people of other ethnic and racial backgrounds. While there are no official and reliable statistics of religious practitioners in Latin America (Hurteau, 2013), it is reported that a great portion of Afro-Latin religious believers are found in Brazil, Cuba and Haiti. Besides these integral believers, informants that I interviewed in the three countries also recounted the significant numbers of visitors that flock regularly to the Caribbean (and Brazil) to be initiated into these religions, or to seek for healing through these faiths.

\section{Candomblé in Brazil}

My significant experience of this Afro-Brazilian religion was back in 2016. I had traveled to Brazil for the second time to accomplish my aspiration of visiting the state of Bahia, where the primary African slaves in Brazil were moved from the African continent. In Bahia, I primarily visited Porto Seguro, a historic city where in 1500 the first Portuguese invaders landed and initially enslaved Native Americans in the area before they began to import African slaves (Bethell, 1987).

It was in Porto Seguro that I met my informant randomly. Mr. Pires Teixeira de Freitas, an artist whose artwork extraordinarily depict symbolic representations of the worshiped goddesses 
(orixás) of Candomblé, such as osun. Worshippers of the orixás are recognized through their all white clothing and distinguished beads.
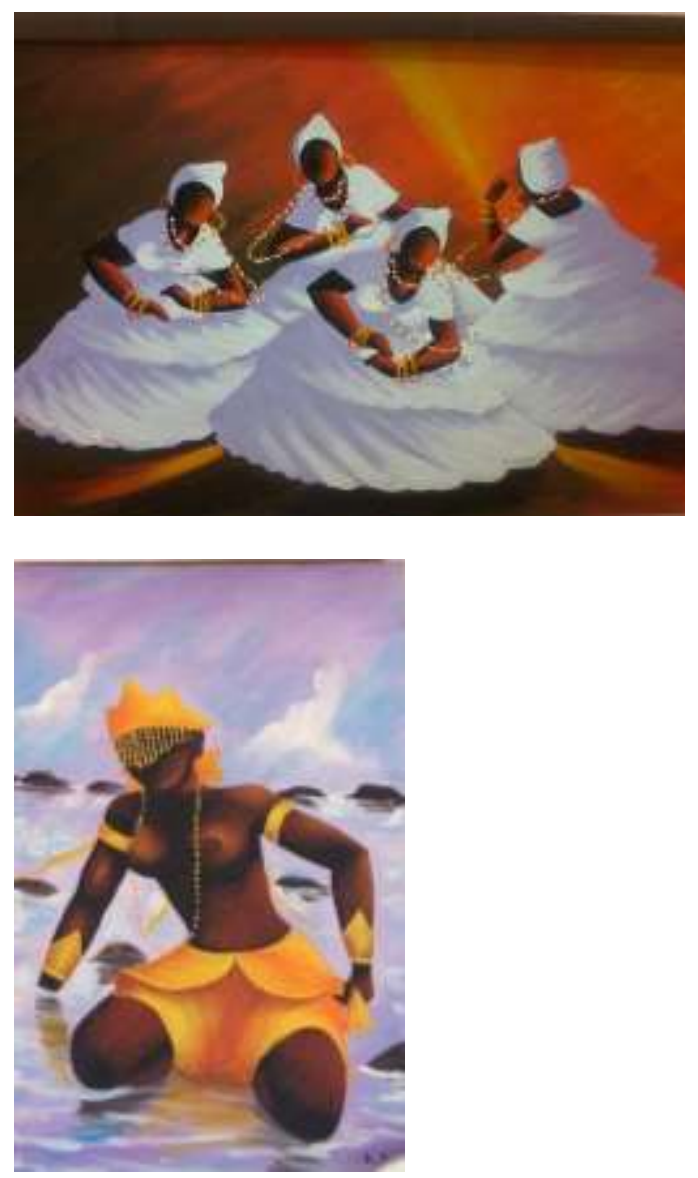

Figure 1. Mr. Freitas' paintings of the dancing Candomblé believers (left) and Oxúm (right), the Orixá of love. 19 December 2016. Photos taken by the author.

Mr. de Freitas explained his dedication to Candomblé through his artwork that portrays African goddesses and gods (deities). He described his work (Figure 1) as an honour and celebration of his African ancestry, recognizing Candomblé as a way of worshiping his ancestral spirits. "Candomblé is the mixture of Yoruba, Fon and Bantu traditional spiritual faiths", he narrated. The religion predominantly incorporates traditional beliefs from the three already ethnically and linguistically diverse groups as African slaves attempted to preserve their individual religious traditions during their enforced relocation from Africa to Brazil (BBC, 2009).

Candomblé is a fusion of religious beliefs from Central to West Africa. According Johnson (2006), Candomblé faith was initially based on the concept of Nkisi (inquices in Brazilian Portuguese), spiritual power figures of Bakongo people in what is today Angola and Democratic Republic of Congo. Along with Ambundu people, who live in their close proximity, the Bakongo people were imported into Brazil three centuries earlier before the arrival other slaves from West Africa (Alencastro, 2018). While Murrell (2010) only clarifies the original name of Candomblé to be "Kandombele", Megenney (2006) establishes the stem of the noun to be derived from Kikongo words of Nkàndu (small drum) and mbé (an expression for the sound made when beating the drum). Candomblé was therefore a musical festival before it was eventually transformed into ritual 
enactments and the usage of sacred medicine as it is still done today (Murrell, 2010; Megenney, 2006).

Although the original concept and practice of this religion is mainly identified with Bakongo slaves in Brazil, Candomblé is also noted to have developed from the notions of other Bantu spirituality and languages, such as Kimbundu. University of Pittsburgh (2009) and Alencastro (2018) supportively associate Candomblé to Banzo, a Kimbundu word derived from the verb kubanza, which translates "to calculate, or to think". According Alencastro (2018), Banzo was used to describe the depressive feelings of the slaves after they were separated from their families (and friends) in Africa, and then shipped to a foreign nation of Brazil. While suffering: being violated, exploited, underfed by their masters, and with no hope of being repatriated, it is said that the Banzo instilled the faith of Candomble in slaves, who eventually formed alternative community and substitute family (University of Pittsburgh, 2009).

Murrell (2010) further notes that, while the creolized Candomblé is of Bantu origins, the religion is largely combined with belief systems and cultic practices of Yoruba faith. As a result, the most influential branch of Candomblé is Ketu (Queto in Portuguese), which uses a sacred language of Yoruba known as Nagô to speak to spirits or deities of Yoruba (Murrell, 2010). The creolization of the religion demonstrates its multiplicity yet integration of distinct cultures and traditions from West and Central Africa.

In Candomblé, there is a well preservation of significant African goddesses/gods (or deities as referred to in many Western literatures) whose worshiping is invested divine powers collectively referred to as Orisha (also spelled as Orișà in Yoruba and Orixá in Portuguese). According to Ademuleya (2007), in Yoruba language, Orișà denotes the origin and essence of a being, the personality or soul. The Orixá in Candomble serve as mediators between the Supreme God of Olorun/Olodumaré and practitioners (Murrell, 2010). According to some literatures (such as Merriam-Webster,1999; Murrell, 2010), there existed hundreds of Orixás in Brazil but today only around 16 are worshipped or celebrated during Candomblé ceremonies in the country. The worshiping of various Orixá is one of the main characteristics that distinguish Candomblé believers from similar beliefs in Africa, where a group of people would only worship one Orixá (University of Pittsburgh, 2009). Considering that slaves had come from various regions of Africa, it is practical for Candomblé religion in Brazil to acknowledge different Orixá.

The Orixá, which are constructed in human thoughts of Africa and summoned in Brazil - are awakened and nurtured through rituals. They humanize forces of nature such as oceans/rivers, thunder/storms, etc. Murrell (2010) and the University of Pittsburgh (2009) highlight the remarkable Orixá mythically believed to hold divine powers as summarized in the following table:

Table 1.

List of some significant Orisha in Candomblé. These Orisha bear African origin names, particularly from Yoruba language. Source: Murrell (2010) and the University of Pittsburgh (2009).

\begin{tabular}{|l|l|}
\hline Orixá & Associations \\
\hline Obatalá/Oxalá & Son of Olorun and creator of human bodies \\
\hline Exú & God messenger, malicious Satan and sacrificial offerings \\
\hline Oxúm & Goddess of sweet, fresh water and sensual love \\
\hline Ogum and Oxossi - Ode & Brothers: god of iron, steel, war and revolution and god of hunting \\
\hline
\end{tabular}




\begin{tabular}{|l|l|}
\hline Yemanja/lemanjá & Mother of several gods, water, lives in the sea \\
\hline Xango & Fire, thunder, lightning \\
\hline Yansa/lansa & Xango's wife thunderstorm, lightning \\
\hline Ibêji & Children, fun, and cheerfulness \\
\hline Nanã & Very old goddess, lives in the marsh \\
\hline Obaluaé/Omolu & Suffering, disease healing \\
\hline Osain/Ossaim & Medicinal herbs/medicine \\
\hline Oxumaré & Rainbow \\
\hline
\end{tabular}

Although sometimes spelled distinctively as a result of the Portuguese influence, the presented names of the significant Orisha and their associations in Candomblé are generally matching with the ones in Yoruba culture in West Africa. Davis (1999) indicates that the presence of mixed African customs from various ethnic groups in Brazilian culture is significant to this date, particularly in the language and religion.

Besides the Yoruba spiritual names, Bantu languages such as Kikongo, Umbundu and Kimbundu are revealed to be the origin of words for certain objects or acts that were significant to slaves. Terms such as fubá (corn meal), mocambo (escaped slave community), samba and maxixe (traditional dances) are indicated by Davis $(1999$, p. 7) to have been derived from these related languages. These terms are used in standardized Brazilian Portuguese to this date.

Africans slaves in Brazil left behind remarkable footprints in Catholicism. Murrell (2010) notes that the Portuguese slave masters required slaves to form irmandades (Brotherhood) based on different social groupings such as ethnicity and nationality. This was done with claims that it would serve several social and religions functions but in reality it was solely a strategy to control the slaves through divide and rule tactics. This kind of division might have been the strength that slaves used to maintain part of their languages and religions through Catholic saint-ism.

Today, Candomblé is amenably integrated in Catholicism with followers from different racial and ethnical backgrounds in the country and beyond. The religion maintains its significant prominence in Brazil where millions of Brazilian identify themselves as Candomblé practitioners (University of Pittsburgh, 2009).

Based on my observations, the presence of African languages and spirituality is preserved in Candomblé and Portuguese spoken in Salvador de Bahia. Salvador, the Capital of Bahia is reported to be the first place to receive African slaves in Brazil. I felt the déjà vu as I walked in the streets of Salvador, particularly around Pelourinho; a neighborhood that left me with imagination of what Africa would have looked like culturally before or during slavery and colonialization. The considered ordinary spiritual and cultural representations of Africa in Salvador de Bahia are more than that I have seen on a regular day in the Central Business District (CBD) of Windhoek in Namibia. The presence of traditionally weaved baskets and women wearing what we know in my language as oilanda (beads), locally known as contas in Bahia - is significantly extraordinary. The contas represent their Orixá. 
I also came across (ou)mbulumbumbwa, a musical instruments made with a single string, musical bow and dry calabash. This instrument is known as a traditional musical instrument among various Bantu-speaking people and can be found in Central, Eastern and Southern Africa (Shaffer, 1977). In Brazil, it is known as berimbau in Brazil. Kubik (as cited in Watson, 2017) supports the idea of the etymology of berimbau to be mbulumbumba ( $\mathrm{sic}$ ) for its construction and techniques including the tuning and playing. Given such origin, it is probable that the knowledge of manufacturing this instrument was transported by the Ovawambo, particularly Ovakwanyama who were captured during slavery. "The Portuguese interests in southern Angola grew gradually. By the 1760s, Portuguese settlers in Benguela managed to establish contacts with the Humbe along the Kunene River, who supplied small numbers of slaves to the Atlantic slave trade. In the process they seized slaves from the agropastoral people - including the Ovambo" (Gustafsson, 2005, p33). The Berimbau is not only recognized as a musical soul of capoeira dance - an African origin martial art of dances and acrobatic, said to have been brought into Brazil by Angolan slaves, but also forms part of the tradition of Candomblé.

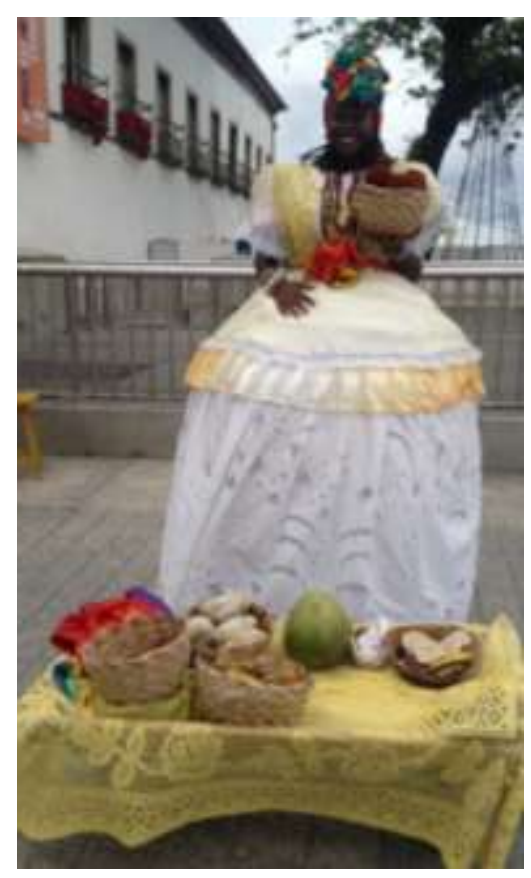




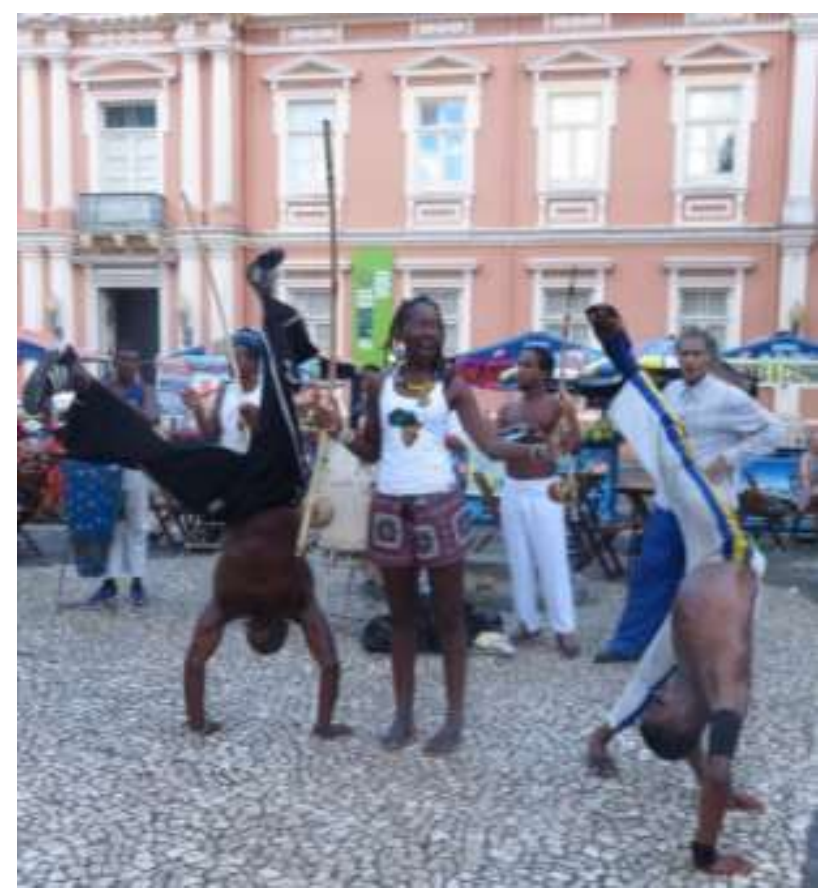

Figure 2. Preserved Africa materials and Capoeira dances in the streets of Salvador de Bahia. 21 December 2016. Photos taken by the author.

\section{Santería in Cuba}

I traveled to Cuba in February 2018 not only to learn about Santería, but also in search of reconnecting with my mother's younger spirit. My mother, who passed away 18 years ago, was among a group of Cassinga (Angola) massacre survivors in 1978. After the attack of Cassinga by the army of the colonial South Africa, some of the survivors were flown to Cuba for safety and better educational opportunities. My mother spent ten years in Cuba before returning to Southern Africa and eventually Namibia where she died ten years later.

I had learned about Cuba-Africa modern relations through the narrations of my mother and her experiences before her passing. She was my primary source of information ranging from Cuba being one of the very few countries in the world to give Africans opportunity to good education a privilege most were denied while being colonized by dominant European countries, to the cultural influence Africa has had on Cuba. Both my spiritual yearning regarding my mother and the little history I learned about Cuba enhanced the desire to travel to Cuba for years until I could finally do so in 2018.

Cuba was not always in favourable support of Africans or their culture as in recent cases. On the contrary, during Cuba's colonial era by the Spanish, a group of Africans who were captured on the African continent were sold and forcefully relocated to Cuba as slaves. This happened between fifteenth and eighteenth centuries (Murrell, 2010). The progressive and positive shift in the perception of African people in the country only occurred during the Cuban Revolution led by Fidel Castro between 1953 and 1959, presenting an opportunity to Afro-Caribbean cultures to further enrich cultures in the United States, Canada, and as far as Europe (Murrell, 2010).

Like the case of Candomblé, Santería developed from the traditional spiritual beliefs of African slaves, predominantly from Yoruba religion, merged with Catholicism and religions of the indigenous peoples of the Americas. This is according to one of my informants, Lucy. I assume 
the complex yet enriching history of Santería religion to be young provided that African descendants could only freely practice their culture and religion after the Cuban Revolution.

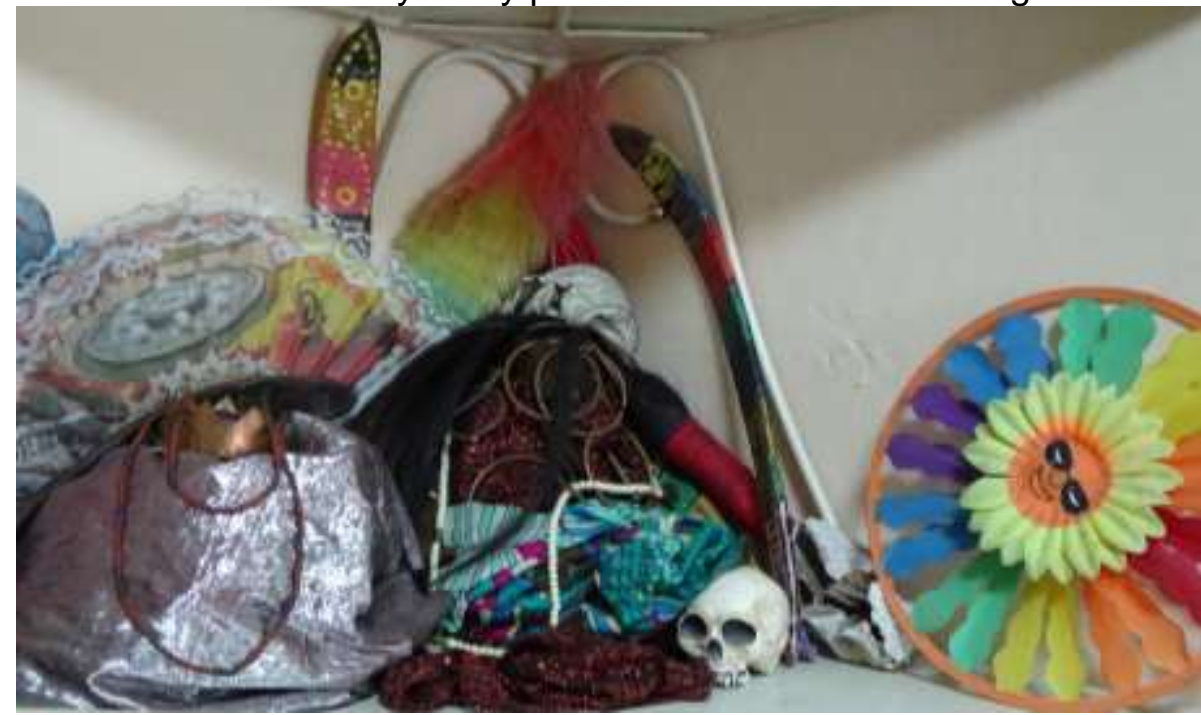

Figure 3. Santería altar in a house in Havana, Cuba. 14 February 2018. Photo taken by the author.

According to Murrell (2010), Santería was initially a derogatory term given to distinguish AfroCuban spirituality from the white Cuban Catholics in the 1940s. It is against this origin that some practitioners and scholars opt to refer to the same religion as Lucumi, Abakua, Ayoba, or La Regla de Ocha / La Regla de Lucumi, which can be translated as "the order of the Orichá" / "the order of Lucumi", respectively. All these aliases are either derived from Yoruba or Kikongo ethos, undeniably validating the notion that the religions firmly established from African traditional spirituality.

The Orichá as the Cuban Spanish way of spelling the Yoruba origin Òrișà (Orixá as explained in Candomblé) are well documented in other Afro-Caribbean religions, derived from African languages, cultures and religions. The Orichá of Lucumi may have been derived from the people of Ulkamy (also called Ulcami, Ulcama, Ulkami, and Ulkumi) found in the ancient Benin (Murrell, 2010, p97). Conversely, Lucumi may also have evolved from oluku mi, which means "my friend or dear one" in Yoruba language. According to Kuyebi (2008), Lukumi was a name given to all Yoruba descent slaves in Cuba, namely: The Egba, Egbado, ljebu, ljesa, Awori, Ketu, Ekiti, Oyo, Ife, or Kwara, who would call themselves Lucumi to address their sisterhood and brotherhood as their way of exchanging greetings.

Like in Candomblé, practicing African spirituality in Cuba was banned by Catholics, in this case by Spanish slave owners. Lucy, the informant articulated that: "in order for the slaves to preserve their Orichá, Lucumí believers shielded their gods(ses) or deities by syncretizing them with Catholic saints' names", meaning that the Orichá had both original African and Catholic names to protect their identities. Believers continued worshiping their Orichá, and sometimes secretively performed African rituals during saints' days as they kept their idols hidden in their homes. After the abolishment of slavery, Afro-Cuban campaigned in solidarity to defend their religion against various prejudices that were spread by Cuban white elites; stereotypes and fabrication that AfroCubans were violent including sacrificing humans during their rituals - were eventually renounced (Murrell, 2010).

Santería is based on the tradition that God has many agents called Orichá created by Olodumare (the distant deity). The Orichá who have human-like characters and personality are endowed with 
the power by Olodumare to work as his substitutes in the natural and spiritual world, therefore creating ache (asé in Yoruba), a life-force implanted in all beings: the living and non-living (Murrell, 2010 \& Sanchez, 2000). Orichás are believed to manage the followers' destinies by guiding them towards the right paths.

There are numerous Orichá in Santería and most bear similar names or characteristics as in Candomblé. I present some of the renowned ones in the following table adopted from DeGaust (2015), Gardner (2009) and Kail, (2008):

Table 2.

List of some significant Orichá in Santería, of which most are syncretized with Catholic names.

\begin{tabular}{|c|c|c|}
\hline $\begin{array}{l}\text { Original } \\
\text { Orichá } \\
\text { names }\end{array}$ & $\begin{array}{l}\text { Syncretized } \\
\text { (Catholic) names }\end{array}$ & Associations \\
\hline Yemayá & Mary & $\begin{array}{l}\text { Queen of the sea and salt water, } \\
\text { mother of fish, motherhood, } \\
\text { intelligence }\end{array}$ \\
\hline $\begin{array}{l}\text { Shangó/ } \\
\text { Changó }\end{array}$ & Saint Barbara & $\begin{array}{l}\text { Lord of fire, thunder and lightning, } \\
\text { virility and strength }\end{array}$ \\
\hline Elegua & Saint Anthony & Cheerfulness \\
\hline Ochún/Oshun & Lady of Charity & $\begin{array}{l}\text { female qualities; coquettishness, } \\
\text { obedience, hard-working, } \\
\text { beautiful, a flatterer }\end{array}$ \\
\hline Obatala & Our Lady of Mercy & $\begin{array}{l}\text { Intersexual with both feminine } \\
\text { and masculine paths }\end{array}$ \\
\hline Oggún & Saint Peter & Iron \\
\hline Ochosi & Saint Norbert & Hunting warrior \\
\hline Oyá & $\begin{array}{l}\text { Lady of } \\
\text { Candelaria and } \\
\text { Saint Theresa }\end{array}$ & $\begin{array}{l}\text { Owner of the cemetery, } \\
\text { gatekeeper }\end{array}$ \\
\hline
\end{tabular}

Today, Santería is openly incorporated in Cuban Catholic religion and society at large, forming a significant part the country's cultural and historic heritage. Almost every Cuban I met and had a conversation with during my visit practices Santería. Devotees of Santería often had a reserved place for their particular Orichá idol in their living room, where they openly display it and a quick ritual can be performed at any time of the day. 


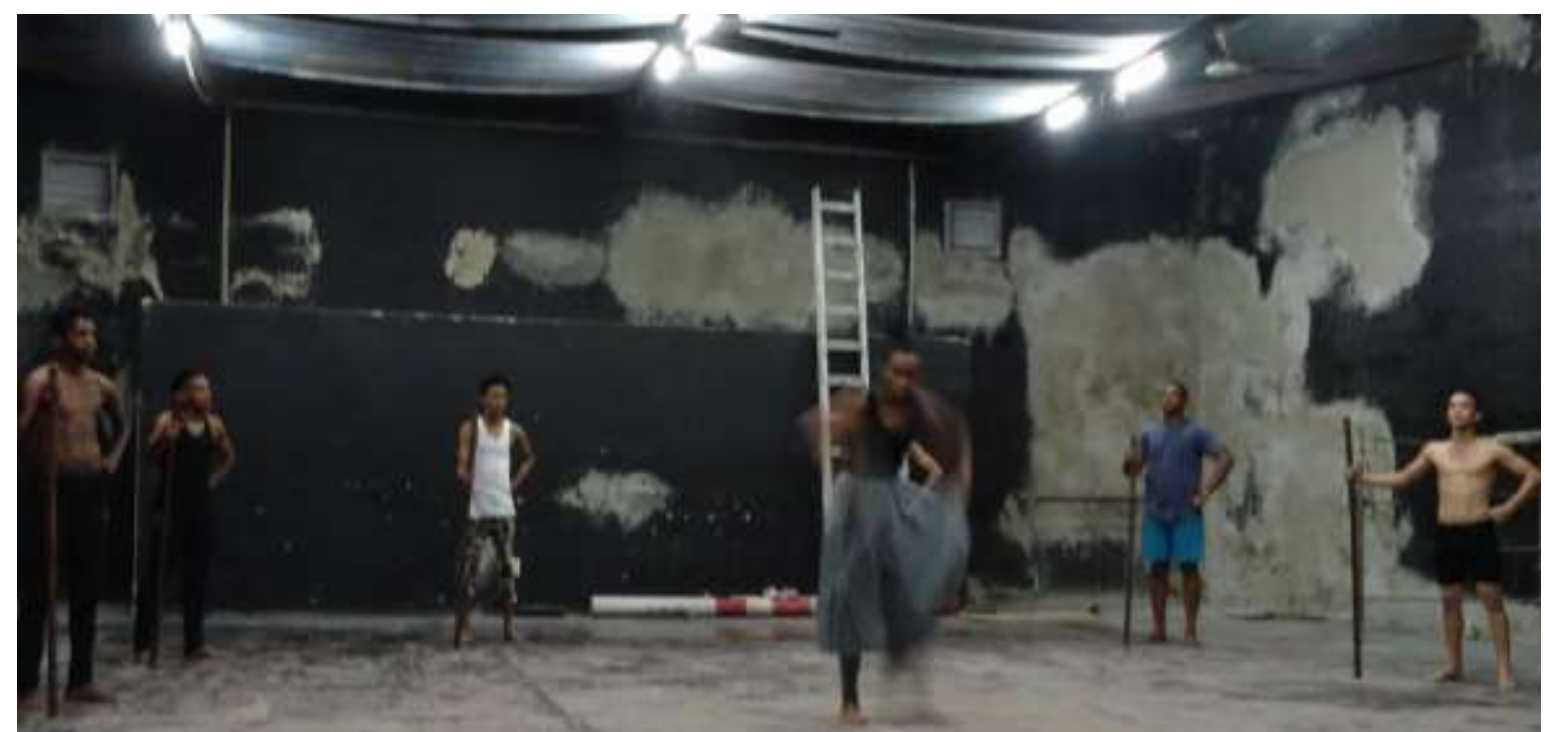

Figure 4. Students performing a ritual dance to Yemayá. 26 February 2018. Photo taken by the author.

\section{Vodou in Haiti}

My very first experience of anything about Haiti was in a Hollywood film, Voodoo Dawn (1989). The film depicted a Haitian female character who would use a doll, a so called "voodoo" doll to harm or kill European characters through a spell or magic. It was in this movie that I learned the existence of voodoo, spelled as "Vodou" in Haitian Creole. This movie like many other North American movies often stereotypically portrayed Haitian Vodou as dangerous. This kind of generalization reminded me of how practicing tradition rituals in parts of Africa are generally referred to as witchcraft or pagan, a negative oversimplified representation of African religions.

Vodou is stereotyped as the most primitive religion in the Caribbean, probably because it is less entwined with Catholicism. The substantial origin of Vodou is reported to be "the serpent cult" of Dahomey and the kingdom of Arada in the current Benin and Togo, where the religion is still practiced by the majorities in the two countries up-to-this-date (Murrell, 2010). Murrell (2010) further explains that in Fon-Dahomey language, Vodou may mean: serving the spirits, sacred objects and so on. Vodou characterizes a set of divinities and ritual dances that harmonize the community with the spirits and mutual relationships.

Contrary to the movie with Vodou dolls, my personal visit to Haiti in March 2018 gave me a variety of insights about the religion. The historical practices of Vodou religion in Haiti, particularly during slavery is an extraordinary one. It is reported in Murrell (2010) that the momentous Haitian revolution, which was started by slaves from different parts of West (and Central) Africa in Hispaniola led it to be the first black republic nations in history and the second in the Americas to gain independence. Hispaniola was initially ruled by the Spanish before France took over SaintDominique to enhance its gross national product through the exploitation of over a million African slaves.

Mason (2015) indicates that the revolution started in August 1791 at 'ceremony at Bois Caûiman', which was both a religious and political event led by a Jamaican-born slave called Boukman Dutty as an oungan (priest) along with an African-born priestess. At the event, a pig was sacrificed to symbolize wild, free, untamable spiritual power of the forest and the ancestors. Eventually, an oath was taken, and Boukman and the priestess urged the listeners to fight bravely against their oppressors. "Days later the Haitian Revolution began" (Mason, 2015, p. 8). With concrete potency 
while possessed by the Vodou of the African spirit of Ezili Kawoulo, slaves fought until death for their freedom.

One of my informants, Ms. Etienne, indicated that during the uprising, Haiti was also renowned to be the country where rebellious slaves from other countries in the Americas would be dumped in for being disobedient. It is probable that Boukman was transferred to Haiti from Jamaica for such a reason.

According to Ampadu (2012), Vodou is a religion and not superstition as many outsiders perceive it; he explained some of the significant goddesses/gods collectively known as loa as I summarize below:

Table 3

List of some significant Lao in Vodou. The Lao are of African origin. Source: Ampadu (2012).

\begin{tabular}{|l|l|}
\hline Loa & Associations \\
\hline Bondye & Creator, good God \\
\hline Iwa & $\begin{array}{l}\text { Spirits of family members and of major forces of the universe: } \\
\text { good, evil, reproduction, health }\end{array}$ \\
\hline Marassa & $\begin{array}{l}\text { Twins, contradictory forces such as good and evil, or happy and } \\
\text { sad }\end{array}$ \\
\hline Baron Samedi & $\begin{array}{l}\text { The dead who are not yet reclaimed; ignored dead are dangerous, } \\
\text { honoured and cared ones helpful }\end{array}$ \\
\hline
\end{tabular}

Furthermore, it is indicated by Ampadu (2012) that in Vodou, humans are believed to have a body and two spirits: Ti-bon-ange (little good angel) and Gros-bon-ange (big good angel). The names of the Loa are creolization of Fon language of West Africa and French among other languages.

Healing people from illness is central to Vodou religion and healers cure with herbs, faith healing with the help of Iwa and other spirits. Haiti, based on my observation felt like Africa in so many cultural, linguistic and social aspects. I spent my first three days in Port-au-Prince upon arrival. Even in the capital city, where one would expect little to no traces of African culture due to modernity, African culture is embraced. African contemporary cultures, particularly from West Africa are also assuredly presented through modern music and clothing. One could get a puzzling impression that Haiti was physically much closer to the African continent than the country's actually neighbours of Dominican Republic and Cuba, who are ethnically/racially diverse.

I could observe many features of African cultures in Port-au-Prince, but like any other big city, characterized by density of population, traffic congestions, and intense speed of life - finding an "authentic" and knowledgeable Vodou priest or practitioners was challenging.

It was during my visits to the commune Les Cayes and the city of Jacmel that I met someone who had sufficient knowledge about Vodou. In the town of Camp Perrin in Les Cayes, I visited a Vodou community and had an interview with oungan, who indicated that many are absolutely misinformed about Vodou practices. "Not all Vodou is bad; here we only practice good Vodou. All members come here to honour and feed the spirits as we dance to the drums, sing, and say our prayers", he said in Creole through interpretation. 
I learned that a number of Haitians, including those who may identify themselves as Christians believe in Vodou; they literally go to church during the day on Sunday and practice their Vodou during the night or any other day besides Sunday. Some believers opt to not openly practice it due to taboos that still exist in the Haitian society about the religion. According to oungan, there are about 101 spirits in Vodou that are acknowledged to have empowered and liberated Africans from Slavery in Haiti. My friend, Davidson, who was interpreting the discussion for me had his own comments about the religion: "it is because we no longer honour these spirits that we now and then have crises in our country, especially natural disasters. Haitians need to show more respect to the spirits, specifically by not cutting down trees, which are homes to our spirits and a source of traditional medicine", he said. This means that elements of nature are significant in Vodou hence if maintained, the religion could contribute to ecological sustainability of the highly deforested Haiti while preserving the African spiritual practices.
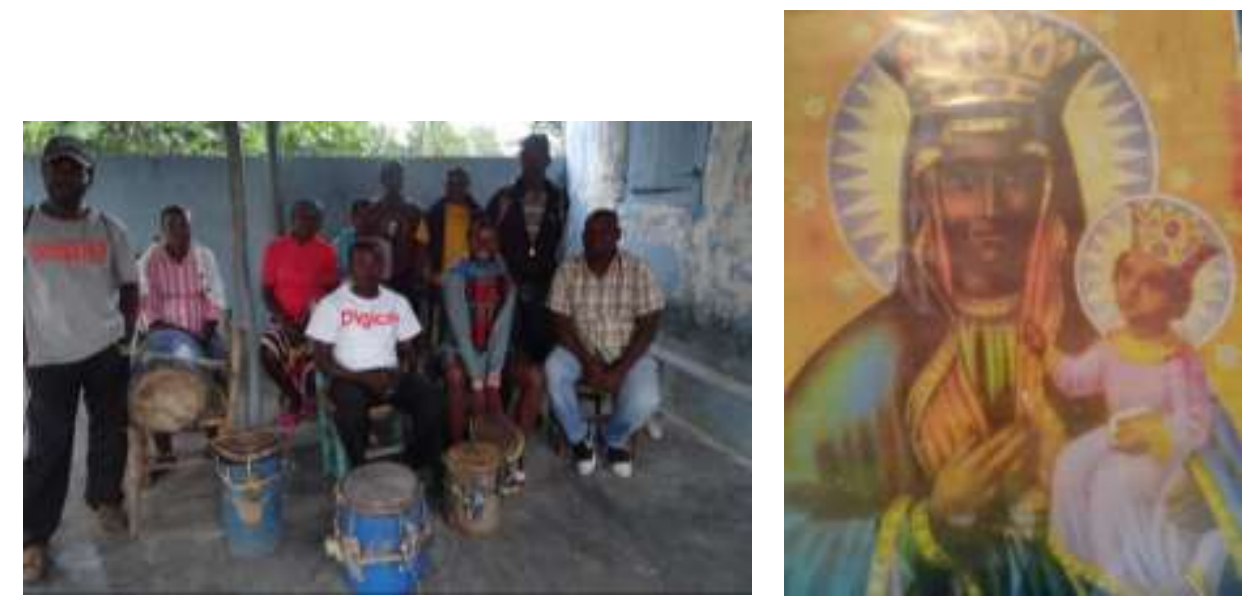

Figure 5. Vodou community (left) in Camp Perrin and an image of Ezili (right) one of the most popular female Iwa. 4 March 2018. Photos taken by the author.

There are also Haitians who acknowledge the existence of Vodou but are not practicing it due to dreadful experiences they had. My informant, Sidney from Jacmel told me that he was almost killed by his adopted sister who casted a magic spell on him and mystically "shot him in his sleep few years ago", he recounted as he showed me the scar on his forehead. He explained that the only reason he survived was because he managed to wake up from the sleep as soon as possible. His sister is still on the run. He also is often bothered by the "shape shifters", especially when driving at night: "suddenly you may see a dog or chicken in the middle of the road, which you better just hit; it disappears. If you swerve to avoid it, you could get really hurt or die in an accident", he said.

Whereas some see Vodou as a blessing, others may see it as a curse, or both. Sidney's worker, "Rasta" had to come to work late the day of my visit because his 125 years old grandmother asked him to take her to church for the last prayer as she believed she was dying. "My grandmother keeps dying and returning to life, it is a blessing to have her at that age, but she should go rest", he said. Rasta said he has watched her grandmother seemingly losing her life various times but she always returns hours later. "For some reasons she often demanded food after she come back to life. "Sometimes I just wish she could die and not return, because she is too old", he said.

\section{Conclusion}


This paper validated the existence of the African religions in the Americas, particularly in Brazil, Cuba and Haiti. The origins of three religions: Candomblé, Santería and Vodou, are deeply rooted into spiritual practiced of West and Central Africa, where the majority of African slaves were captured and transferred from. The Yoruba, Fon and Bakongo are among influential languages and cultures on the concepts around the three religions, with significant names of renowned goddess/gods or deities derived from these African languages. During slavery, the governing Catholic Church attempted to dismiss the spiritual practices of the slaves by brutally prosecuting believers. Consequently, Catholicism became a shield their African belief and deities were syncretized with catholic names to hide their identities as slaves practiced their traditional beliefs secretively. Today, Candomblé and Santería are official integrated into Catholicism whereas to Vodou primarily remains as customary as in countries in West Africa, such as Benin and Togo, where it is practiced to date.

The findings of this paper validates the progression of African based religions in Latin America. While evaluating their current statuses and sustenance on the study focus region, it was knowledgeable to learn and witness African religions being preserved conceivably successfully than in many parts of Africa. Findings of this study are relevant in literatures of languages and cultures as diverse African traditions and practices are threatened to extinct on the continent even before proper documentation. It is therefore immensely important for more research to be done to improve visibility of the prominence relation Latin America has with Africa, especially with regards to the existence of African cultures including languages and beliefs in Latin America since slavery.

\section{References}

Ademuleya, B. A. (2007). The concept of Ori in the traditional Yoruba visual representation of human figures. Nordic Journal of African Studies, 16(2), 212-220.

African Religions. (1999). Merriam-Webster's Encyclopedia. Wendy Doniger, consulting editor. Springfield, Mass: Merriam-Webster.

Alencastro, L. F. (2018). The trade in the living: The tormation of Brazil in the South Atlantic, sixteenth to seventeenth centuries. Fernand Braudel Center Studies in Historical Social Science: SUNY Press.

Ampadu, C. (2012). The power of Voodoo to impoverish and enslave a nation. Disciple Nations Alliance. Retrieved from https://www.disciplenations.org/media/HaitianVoodoo Ampadu.pdf

Bialostocka, O. (2015). 'I believe in one God' or the issue of teaching religion in Namibia. Policy Brief 116, Africa Institute of South Africa (AISA), Pretoria. Retrieved from http://www.hsrc.ac.za/uploads/pageContent/5805/2015AISA-lbelieveinoneGOD.pdf

Bethell, L. (1987). Colonial Brazil. Cambridge, New York: Cambridge University Press.

Candomblé at a glance. (2009, September 15). British Broadcasting Corporation. Retrieved from http://www.bbc.co.uk/religion/religions/candomble/ataglance/glance.shtml

Davis, D. J. (1999) Afro-Brazilians: Time for recognition. Minority Rights Group International Report. Retrieved from https://minorityrights.org/wp-content/uploads/old-sitedownloads/download-142-Afro-Brazilians-Time-for-Recognition.pdf

DeGaust-Hunderi, K. T. (2015). Cuba, Santería and the dances of the Orichas (Master's thesis dissertation). University of Bergen. Retrieved from http://bora.uib.no/bitstream/handle/1956/11656/141911267.pdf;sequence=1

Gardner, L. (2010). Cults of the saints: An introduction to santeria. The L/wellyn Journal. Retrieved from http://www.llewellyn.com/journal/article/2048

Gustafsson, K. (2005). The trade in slaves in Ovamboland, ca. 1850-1910. African Economic History, 33, 31-68. 
Heine, B., \& Nurse, D. (2000). In African languages: An introduction. Cambridge, UK: Cambridge University Press.

Hiltunen, M. (1993). Good magic in Ovambo. Helsinki: Finnish Anthropological Society.

Hurteau, P. (2013). Afro-Caribbean and Afro-Brazilian religions. Male homosexualities and world religions. 157-175. Retrieved from https://doi.org/10.1057/9781137340535 7.

Johnson, P. C. (2006). Secrets, gossip, and Gods: The transformation of Brazilian Candomblé. Nova Religio. The Journal of Alternative and Emergent Religions, pp. 129-130.

Kail, T. M. (2008). Magico-religious groups and ritualistic activities: A guide for first responders. Boca Raton, FL: CRC Press.

Karade, B. I. (1994). The handbook of Yoruba religious concepts. York Beach: ME, Samuel Weiser.

Kautondokwa, E.T. (2014). Olufuko revisited: Female initiation in contemporary Ombadja, Northern Namibia (Master's thesis dissertation). University of the Western Cape. Retrieved from http://etd.uwc.ac.za/xmlui/handle/11394/4118

Kuyebi, A. A. (2008). Osun of Osogbo and Osun in the new world: The mythological religious study of a Yoruba goddess (PhD thesis). University of Manitoba. Retrieved from https://mspace.lib.umanitoba.ca/xmlui/handle/1993/21119.

Mason, J. (2015). African religion in the Caribbean: continuity and change. Retrieved from https://www.kislakfoundation.org/millennium-exhibit/mason1.pdf

Megenney, W. W. (2006). Afro-Brazilian percussion instruments: Etymologies \& uses. Revista del CESLA, [S.I.], n. 9, 25-35. Retrieved from http://www.revistadelcesla.com/index.php/revistadelcesla/article/view/214

Murrell, N. S., 2010. Afro-Caribbean religions: An introduction to their historical, cultural, and sacred traditions. Philadelphia: Temple University Press.

Omoregbe, N., Azeta, A., Adewumi, A., \& Omotoso, O. O. (2014). Design and implementation of Yoruba language mobile tutor. Proceedings of 6th international conference on education and new learning technologies. (3942-3947). Spain.

Sanchez, S. M. (2000). Afro-Cuban diasporan religions: A comparative analysis of the literature and selected annotated bibliography. Institute for Cuban \& Cuban-American Studies Occasional Papers.27. Retrieved from https://scholarlyrepository.miami.edu/iccaspapers/27/

Shaffer, K. (1977). O berimbau de barriga e seus toques. Rio de Janeiro: Ministério da Educação e Cultura.

University of Pittsburgh. (2009). A brief overview of Umbanda and Candomblé. Retrieved from http://www.ucis.pitt.edu/clas/sites/default/files/activity_sheet.pdf

Watson, N. W. (2017). Key factors in the evolution and globalization of the Berimbau: How the Brazilian musical bow overcame social and musical limitations and became a global icon of music, culture and spirit (Master's thesis dissertation). University of Miami. Retrieved from https://scholarlyrepository.miami.edu/cgi/viewcontent.cgi?article=1673\&context=0a_thes es 